Vol. 9, No. 2, pp. 45-61, Oktober 2021

PEDAGOGI: JURNAL PENDIDIKAN DASAR

http://jurnal.fkip.unila.ac.id/index.php/pgsd

\title{
Hubungan antara Fasilitas Belajar di Sekolah dengan Hasil Belajar Peserta Didik Kelas V di Sekolah Dasar Negeri
}

\author{
Indah Purnama Sari \\ Pendidikan Guru Sekolah Dasar, Universitas Lampung \\ Jl. Prof. Dr. Sumantri Brojonegoro No 1 Bandar Lampung \\ Email: indahpurnama290799@gmail.com
}

\begin{abstract}
Article Info
Abstract

Received Oktober 2021

The problem in this reseach is the low learning outcomes of grade $V$

Revision Oktober 2021 students at SD Negeri 01 Gapura. The purpose of this study was to analyze

Published Oktober 2021 and know the significant relationship between learning facilities and learning outcomes of class $V$ SD Negeri 01 Gapura. The research method uses is quantitative. The population was 40 students and using saturated

Keywords:

learning outcomes, samples. The data collection tool using a questionnaire was tested for validity and reliability. The data analysis technique used product moment correlation formula. The results showed that there was a positive and significant relationship between learning facilities and learning outcomes of class $V$ elementary school students 01 Gapura Kotabumi Lampung Utara.
\end{abstract}

\begin{abstract}
Abstrak: Masalah dalam penelitian ini yaitu masih rendahnya hasil belajar peserta didik kelas V SD Negeri 01 Gapura. Tujuan penelitian ini yaitu untuk menganalisis dan mengetahui hubungan signifikan antara fasilitas belajar dengan hasil belajar peserta didik kelas V SD Negeri 01 Gapura. Penelitian ini merupakan penelitian kuantitatif. Populasi dalam penelitian berjumlah 40 peserta didik dengan menggunakan sampel jenuh. Alat pengumpulan data menggunakan angket, yang telah diuji validitas dan reabilitas. Teknik analisis data menggunakan rumus korelasi product moment. Hasil penelitian menunjukkan ada hubungan yang positif dan signifikan antara fasilitas belajar dengan hasil belajar peserta didik kelas V Sekolah Dasar Negeri 01 Gapura Kotabumi Lampung Utara.
\end{abstract}

Kata Kunci: hasil belajar, fasilitas belajar. 


\section{PENDAHULUAN}

Pendidikan merupakan hal yang sangat berpengaruh dalam menentukan perkembangan individu dan perkembangan masyarakat. Pendidikan dapat membantu manusia dalam mengembangkan diri dan menghadapi masalah yang terjadi dalam kehidupan. Pendidikan merupakan dasar untuk membangun bangsa yang kuat dengan menciptakan manusia yang berpotensi, kreatif, dan memiliki ide cemerlang sebagai bekal untuk memperoleh masa depan yang lebih baik.

Sekolah merupakan bagian utama untuk kehidupan seorang anak selain keluarga dan lingkungan. Secara umum sekolah digunakan sebagai tempat seorang anak di stimulus untuk memperoleh pengetahuan yang di terima dari seorang pendidik. Sekolah juga tempat yang penting bagi peserta didik untuk mengembangkan potensi yang dimiliki peserta didik.

Sebagaimana yang tercantum dalam Undang-undang Sistem Pendidikan Nasional No.20 tahun 2003 (BSNP, 2016), yang menyatakan bahwa:

Pendidikan adalah usaha sadar dan terencana untuk mewujudkan suasana belajar dan proses pembelajaran agar peserta didik secara aktif mengembangkan potensi dirinya untuk memiliki kekuatan spiritual keagamaan, pengendalian diri, kepribadian, kecerdasan, akhlak mulia, serta keterampilan yang diperlukannya serta masyarakat bangsa dan, Negara. (Kemendiknas, 2003: 3).

Berdasarkan undang-undang di atas, dapat dilihat bahwa pendidikan tidak terlepas dari kegiatan pembelajaran yang menuntut out put pendidikan yang berkualitas dengan berbagai kemampuan dan potensi yang dimilikinya. Berbicara tentang out put pendidikan dimulai dari sekolah dasar. Pendidikan di tingkat sekolah dasar merupakan pijakan peserta didik melanjutkan ke jenjang selanjutnya dan mampu membekalinya dengan nilai-nilai, sikap, dan kemampuan dasar untuk menjadi pribadi yang mandiri sejak dini. Usaha peserta didik juga merupakan faktor penentu keberhasilan pembelajaran, saat proses pembelajaran. Jika tidak ada usaha, maka peserta didik tidak akan mencapai hasil belajar yang baik.

Proses pembelajaran yang harus dilakukan di sekolah adalah merencanakan, melaksanakan, dan mengevaluasi kegiatan pembelajaran. Pembelajaran merupakan upaya sistematis dan sistematik untuk menginisiasi, memfasilitasi, dan 
meningkatkan proses belajar maka kegiatan pembelajaran berkaitan erat dengan jenis hakikat, dan jenis belajar serta hasil belajar tersebut.

Menurut Nana Sudjana dalam Widaryanto (2016: 4) "hasil belajar peserta didik pada hakikatnya adalah perubahan tingkah laku. Tingkah laku sebagai hasil belajar dalam pengertian yang luas mencakup bidang kognitif, afektif, dan psikomotorik". Belajar banyak dipengaruhi oleh beberapa faktor, dapat digolongkan menjadi 2 faktor yaitu faktor intern dan faktor ekstern. Faktor intern adalah faktor yang ada di dalam individu, sedangkan faktor ekstern adalah faktor yang ada di luar individu. Faktor intern meliputi faktor jasmaniah, faktor psikologis, dan faktor kelelahan. Sementara faktor eksternal yang merupakan faktor/sebab dari luar diri peserta didik meliputi lingkungan sosial dan lingkungan non sosial, dimana lingkungan sosial meliputi lingkungan sekolah, lingkungan rumah, dan lingkungan masyarakat. Sementara lingkungan nonsosial meliputi jarak rumah dengan sekolah, fasilitas belajar, iklim/cuaca dan waktu belajar. Salah satu faktor eksternal yang mempengaruhi hasil belajar adalah fasilitas belajar. Gunawan (2011: 42) mengemukakan bahwa "fasilitas belajar ialah benda-benda yang siap pakai dalam proses pembelajaran sehingga prosespembelajaran semakin efektif dan efisien guna membantu tercapainya tujuan pendidikan yang telah ditetapkan". Sesuai dengan pendapat Sampson (2011: 701-713) "Found that only a study effort from a student, regardless enough learning facilities, can make a student performance well in education".

Maksud dari pernyataan tersebut adalah bahwa hanya upaya dari seorang peserta didik dan fasilitas belajar yang cukup, yang dapat meningkatkan prestasi siswa dalam bidang pendidikan.

Penelitian ini meneliti fasilitas belajar yang lengkap dan sesuai dengan standar akan menunjang proses pembelajaran yang di laksanakan di dalam kelas, sehingga potensi yang dimiliki peserta didik dapat dikembangkan secara maksimal. Untuk mengetahui suatu sekolah memiliki fasilitas belajar yang memadahi dapat dilihat melalui standar fasilitas belajar.

Menurut Permendiknas Nomor 24 Tahun 2007 bahwa: 
Sebuah SD/MI sekurang-kurangnya memiliki prasarana sebaga berikut: (1) Ruang kelas, (2) Ruang perpustakaan, (3) Laboratorium IPA, (4) Ruang pimpinan, (5) Ruang pendidik, (6) Tempat beribadah, (7) Ruang UKS, (8) Jamban, (9) Gudang, (10) Ruang sirkulasi, dan (11) Tempat bermain/berolahraga.

Sesuai dengan pendapat Khan and Igbal (2012: 211)

"Adequate and quality school facilities are basic ingredients of quality education and to achieve the intended goal of the school program. They also strengthen the idea by emphasizing that learning is a complex activity that requires students and teachers' motivation, adequate school facilities such as standardized buildings and classrooms with their facilities, instructional materials and equipments for child development".

Maksud dari pernyataan tersebut adalah bahwa fasilitas sekolah yang memadai dan berkualitas merupakan bahan dasar pendidikan yang berkualitas dan untuk mencapai tujuan program sekolah yang dimaksudkan. Mereka juga memperkuat gagasan dengan menekankan bahwa belajar merupakan kegiatan kompleks yang menuntut peserta didik dan motivasi pendidik, fasilitas sekolah yang memadai seperti standar gedung dan ruang kelas dengan fasilitas, bahan ajar dan perlengkapan untuk tumbuh kembang anak.

Fasilitas belajar dibagi menjadi dua yaitu sarana dan prasarana. Sarana adalah semua peralatan, bahan, dan perabot langsung yang digunakan dalam kegiatan belajar disekolah misalnya buku pelajaran, alat tulis, media pembelajaran, alat peraga, dll. Sedangkan prasarana adalah semua perlengkapan dasar yang secara tidak langsung menunjang pelaksanaan proses pendidikan di sekolah misalnya ruang kelas, ruang laboratorium, ruang praktik, ruang komputer, UKS, WC, kamar mandi, taman dan tempat parkir.

Peneliti mengambil kelas V sebagai sampel penelitian karena begitu pentingnya fasilitas belajar untuk peserta didik kelas $\mathrm{V}$ yang akan segera mempersiapkan pelaksanaan ujian dan akan segera naik ke kelas VI sehingga diperlukan belajar yang benar - benar di dukung oleh fasilitas belajar yang lengkap dan sesuai dengan standar untuk mendongkrak hasil belajar peserta didik agar lebih baik. Selain itu juga anak pada usia ini yaitu kelas V SD umumnya sudah mampu menggunakan bahasa untuk menjelaskan keinginannya dengan 
lebih jelas dan sudah mampu memahami adanya sebab akibat. Kemudian, anak pada usia ini juga dapat memperhatikan sesuatu dengan durasi yang lebih lama dan suka bereksperimen. Struktur kalimat juga lebih kompleks dan juga sudah memiliki keterampilan naratif yang lebih baik dari pada anak pada usia sebelumnya. Maka dari itu peneliti tertarik untuk melakukan penelitian di kelas V.

Berdasarkan kondisi di SD Negeri 01 Gapura saat peneliti melaksanakan PLP terdapat beberapa fasilitas belajar yang kurang baik untuk digunakan. Hal ini ditunjukkan dengan adanya fasilitas belajar peserta didik yang belum mendukung proses pembelajaran, fasilitas belajar yang ada kurang terawat dengan baik serta penggunaannya belum optimal. Masih terdapat penataan ruang kelas yang belum memadahi sehingga menjadi penghambat peserta didik dalam proses pembelajaran. Kurangnya pemanfaatan media yang disediakan di kelas untuk memperdalam materi. Selain itu, kurangnya pemanfaatan alat peraga yang berada di kelas sehingga peserta didik kurang tertarik untuk mengikuti pembelajaran di kelas. Sejalan dengan permasalahan pendidik, peserta didik juga mempunyai masalah yang serupa. Kurangnya buku pedoman dari peserta didik untuk menambah wawasan dan pengetahuan. Apalagi peserta didik harus berbagi buku dengan teman sebangkunya karena kurangnya jumlah buku yang disediakan oleh sekolah. Banyaknya peserta didik juga tidak memiliki alat belajar yang lengkap. Tentunya hal tersebut menyebabkan hasil belajar tematik peserta didik kelas $\mathrm{V}$ rendah dan masih di bawah KKM, yang dibuktikan pada banyaknya jumlah peserta didik yang nilainya belum tuntas pada Ujian Tengah Semester tahun pelajaran 2021/2022, seperti tabel 1 di bawah ini. 
Tabel 1. Data nilai ujian tengah semester ganjil kelas V SD Negeri 01 Gapura pada Pembelajaran Tematik Tahun Pelajaran 2021/2022.

\begin{tabular}{|c|c|c|c|c|c|c|}
\hline Kelas & KKM & Jumlah & \multicolumn{2}{|c|}{ Tuntas } & \multicolumn{2}{c|}{ Belum Tuntas } \\
\cline { 4 - 7 } & & $\begin{array}{c}\text { Peserta } \\
\text { Didik } \\
\text { (orang) }\end{array}$ & $\begin{array}{c}\text { Jumlah } \\
\text { Peserta } \\
\text { Didik } \\
\text { (orang) }\end{array}$ & $\begin{array}{c}\text { Persentase } \\
(\%)\end{array}$ & $\begin{array}{c}\text { Jumlah } \\
\text { Peserta } \\
\text { Didik } \\
\text { (orang) }\end{array}$ & $\begin{array}{c}\text { Persentase } \\
(\%)\end{array}$ \\
\hline $\begin{array}{c}\text { Kelas } \\
\text { A }\end{array}$ & 70 & 20 & 5 & 25,00 & 15 & 75,00 \\
\hline $\begin{array}{c}\text { Kelas } \\
\text { B }\end{array}$ & 70 & 20 & 5 & 25,00 & 15 & 75,00 \\
\hline
\end{tabular}

Sumber: Dokumentasi ujian tengah semester ganjil kelas V A dan V B SD Negeri 01 Gapura.

Berdasarkan tabel 1 di atas, terlihat bahwa di kelas $\mathrm{V}$ A masih banyak peserta didik yang belum mencapai kriteria ketuntasan minimal yang telah ditentukan yaitu 70, dari seluruh peserta didik kelas V A yang berjumlah 20 orang hanya ada 5 orang atau sekitar $25 \%$ peserta didik yang telah mencapai kriteria ketuntasan minimal dan 15 orang atau sekitar $75 \%$ peserta didik yang belum mencapai kriteria ketuntasan minimal. Sedangkan peserta didik kelas V B dengan jumlah peserta didik yang mencapai kriteria ketuntasan minimal adalah 5 orang atau sekitar $25 \%$ dan belum mencapai kriteria ketuntasan minimal sebesar 15 orang atau sekitar $75 \%$. Rendahnya hasil belajar tematik tersebut diduga karena peserta didik kurang memahami materi yang disampaikan oleh pendidik. Selain faktor peserta didik, faktor pendidik juga berpengaruh terhadap rendahnya hasil belajar tematik. Pendidik belum memanfaatkan fasilitas belajar di sekolah secara maksimal untuk pembelajaran di dalam kelas sehingga peserta didik kurang memahami materi yang disampaikan oleh pendidik. Sehubungan dengan masalah di atas, peneliti tertarik tertarik untuk melakukan penelitian.

Berdasarkan temuan empiris di SD Negeri 01 Gapura, terdapat beberapa peserta didik yang tidak memiliki fasilitas belajar dengan lengkap. Terdapat beberapa fasilitas belajar yang disediakan oleh sekolah kurang menunjang pembelajaran. Hal tersebut menyebabkan kurang optimalnya pembelajaran di kelas, sehingga terdapat beberapa peserta didik yang kurang memahami materi yang disampaikan oleh pendidik yang menyebabkan masih banyak peserta didik yang belum mencapai ketuntasan dalam belajar. Menurut Mulyasa (2008: 207) 
bahwa pembelajaran dapat diakatakan berhasil apabila terjadi perubahan prilaku yang positif pada peserta didik seluruhnya atau setidaknya sebagian besar (75\%) sesuai dengan kompetensi dasar. Selain hal-hal yang telah dijelaskan, terdapat juga fasilitas-fasilitas belajar didalam kelas yang masih dapat dimanfaatkan oleh pendidik dan peserta didik meskipun dalam penggunaannya belum maksimal, misalnya terdapatnya perpustakaan sekolah yang dapat digunakan oleh peserta didik untuk tempat belajar. Tersedianya ruang UKS yang dapat digunakan oleh peserta didik dan pendidik yang mengalami masalah kesehatan. Tersedianya buku-buku pelajaran yang dapat digunakan oleh pendidik dan peserta didik untuk menunjang pembelajaran di dalam kelas.

Tujuan pelaksanaan penelitian ini adalah untuk menganalisis dan mengetahui hubungan signifikan antara fasilitas belajar dengan hasil belajar peserta didik kelas V SD Negeri 01 Gapura. Dengan ini maka dapat diketahui bagaimana pelaksanaan dan tingkat keberhasilan dalam belajar menagajar, baik oleh peserta didik maupun pendidik. Hasil yang diperoleh berupa bagaimana keadaan fasilitas belajar yang ada di sekolah yang berkaitan dengan hasil belajar peserta didik. Hasil penelitian tersebut diharapkan dapat dijadikan sebagai pertimbangan keputusan agar program pembelajaran selanjutnya dapat berlangsung lebih baik lagi.

\section{METODE}

\section{Jenis Penelitian}

Jenis penelitian ini adalah kuantitatif dengan metode penelitian ex-postfacto korelasi. Penelitian ini bertujuan untuk mengetahui hubungan positif dan signifikan antara fasilititas belajar di sekolah dengan hasil belajar peserta didik kelas V SD Negeri 01 Gapura.

\section{Tempat dan Waktu Penelitian}

Tempat penelitian dilaksanakan di SD Negeri 01 Gapura Kotabumi Lampung Utara dan waktu penelitian telah dilaksanakan pada tanggal 20 September 2021. 


\section{Populasi dan Sampel Penelitian}

Populasi dalam penelitian ini adalah seluruh peserta didik kelas V SD Negeri 01 Gapura yaitu 40 orang peserta didik, terdiri dari 20 orang peserta didik kelas V A dan 20 orang peserta didik kelas V B. Sampel dalam penelitian ini menggunakan teknik non probability yaitu sampling jenuh. Jadi, sampel dalam penelitian ini adalah seluruh peserta didik kelas V SD Negeri 01 Gapura yang berjumlah 40 peserta didik. Alasan peneliti memilih sampel jenuh karena populasi dalam penelitian kurang dari 100 peserta didik yaitu 40 peserta didik, sehingga peneliti menggunakan semua populasi menjadi sampel penelitian.

\section{Alat Pengumpulan Data}

Alat pengumpulan data kelengkapan fasilitas belajar diukur dengan menggunakan angket. Indikator variabel dijadikan tolak ukur peneliti dalam menyusun item-item instrumen yang berupa 40 pernyataan. Kemudian, angket dalam penelitian ini di uji kepada peserta didik kelas V SD Negeri 01 Kotabumi Tengah. Observasi dalam penelitian ini dilaksanakan pada saat peneliti melaksanakan penelitian pendahuluan. Selain itu, observasi ini dilaksanakan untuk memperoleh nilai UTS Tematik kelas $\mathrm{V}$, data mengenai kelengkapan fasilitas sekolah dan data tentang kondisi sekolah atau deskripsi lokasi penelitian yang akan dilaksanakan di SD Negeri 01 Gapura. Studi dokumentasi merupakan teknik pengumpulan data yang digunakan untuk memperoleh data mengenai penelitian yang relevan. Dokumentasi dalam penelitian ini digunakan untuk mendapatkan sumber data yang berhubungan dengan penelitian yaitu berupa identitas siswa, pengetahuan tentang jumlah populasi, dan jumlah rombongan belajar di setiap sekolahnya.

\section{Teknik Analisis Data dan Pengujian Hipotesis}

Teknik analisis data yang digunakan dalam penelitian adalah teknik analisis data kuantitatif, pada penelitian kuantitatif kegiatan analisis datanya meliputi pengolahan data dan penyajian data, melakukan perhitungan untuk mendeskripsikan data dan melakukan pengujian hipotesis dengan menggunakan 
uji statistik. Pengujian selanjutnya yaitu uji hipotesis yang berfungsi mencari makna hubungan antara variabel $\mathrm{X}$ terhadap variabel $\mathrm{Y}$.

\section{HASIL DAN PEMBAHASAN}

Berdasarkan hasil penelitian diperoleh data instrumen penelitian yang diberikan kepada peserta didik kelas V SD Negeri 01 Gapura pada tanggal 20 September 2021 dan hasil belajar tematik didapat dari nilai ujian tengah semester ganjil tahun pelajaran 2021/2022. Data tersebut digunakan untuk mengetahui hubungan antara fasilitas belajar dengan hasil belajar peserta didik.

\section{Data Hasil Belajar}

Hasil perhitungan kelas interval sebelum mengetahui frekuensi setiap data nilai. Sesuai dengan perhitungan diperoleh kelas interval dengan panjang kelas yaitu 6, setelah diperoleh kelas interval selanjutnya menentukan distribusi frekuensi. Lebih jelas dapat dilihat pada tabel berikut.

Tabel 9. Daftar Distribusi Frekuensi Variabel Y (Hasil Belajar)

\begin{tabular}{|c|c|c|c|}
\hline No & Kelas Interval & Frekuensi & Persentase (\%) \\
\hline 1 & $45-50$ & 3 & 7,5 \\
\hline 2 & $51-56$ & 6 & 15 \\
\hline 3 & $57-62$ & 8 & 20 \\
\hline 4 & $63-68$ & 12 & 30 \\
\hline 5 & $69-74$ & 7 & 17,5 \\
\hline 6 & $75-80$ & 4 & 10 \\
\hline \multicolumn{2}{|r|}{ Jumlah } & 40 & 100 \\
\hline
\end{tabular}

Tabel 9 terlihat bahwa jumlah frekuensi tertinggi sebanyak 12 peserta didik dengan 30\% menempati kelas interval 63-68 mencapai KKM yang telah ditetapkan yaitu 70. Hal ini berarti fasilitas belajar peserta didik perlu ditingkatkan lagi lebih jelasnya dapat dilihat pada gambar berikut. 


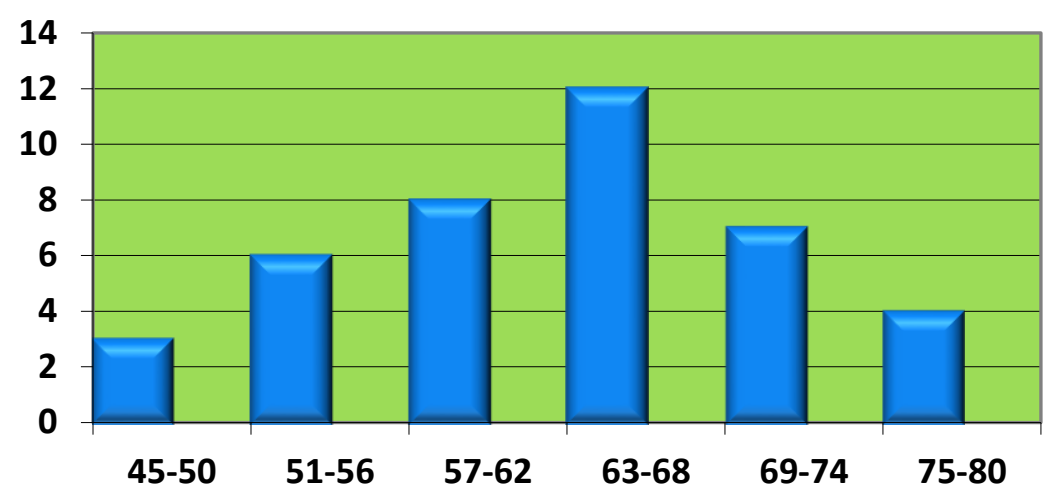

Gambar 3. Distribusi Frekuensi Variabel Y (Hasil Belajar)

\section{Data Fasilitas Belajar}

Hasil perhitungan kelas interval sebelum mengetahui frekuensi setiap data nilai. Sesuai dengan perhitungan diperoleh kelas interval dengan panjang kelas yaitu 6, setelah diperoleh kelas interval selanjutnya menentukan distribusi frekuensi. Lebih jelas dapat dilihat pada tabel berikut.

Hasil perhitungan kelas interval sebelum mengetahui frekuensi setiap data nilai. Sesuai dengan perhitungan diperoleh kelas interval dengan panjang kelas yaitu 6, setelah diperoleh kelas interval selanjutnya menentukan distribusi frekuensi. Lebih jelas dapat dilihat pada tabel berikut.

\section{Tabel 10. Daftar Distribusi Frekuensi Variabel X (Fasilitas Belajar)}

\begin{tabular}{|c|c|c|c|}
\hline No & Kelas Interval & Frekuensi & Persentase (\%) \\
\hline 1 & $40-45$ & 4 & 10 \\
\hline 2 & $46-51$ & 6 & 15 \\
\hline 3 & $52-57$ & 7 & 17,5 \\
\hline 4 & $58-63$ & 12 & 30 \\
\hline 5 & $64-69$ & 6 & 15 \\
\hline 6 & $70-75$ & 5 & 12,5 \\
\hline \multicolumn{2}{|r|}{ Jumlah } & 40 & 100 \\
\hline
\end{tabular}

Tabel 10 diatas menunjukan bahwa fasilitas belajar peserta didik kelas V SD Negeri 01 Gapura harus ditingkatkan lagi. Distribusi frekuensi tertinggi berada pada kelas interval 58 - 63 sebanyak 12 peserta didik. Sedangkan kelas interval tertinggi yaitu $70-75$. Lebih jelasnya dapat dilihat pada gambar berikut. 


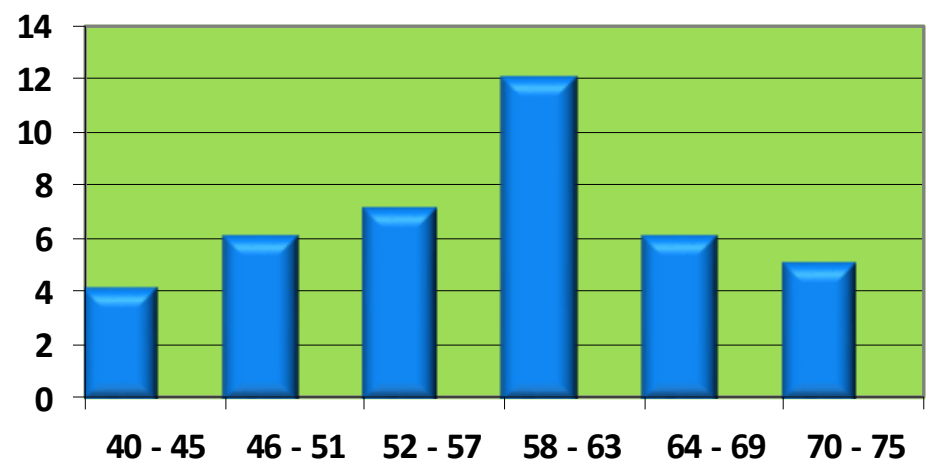

Gambar 4: Distribusi Frekuensi Variabel X

\section{Uji Prasyaratan Analisis Data}

\section{Hasil Analisis Uji Normalitas dan Uji Linieritas}

Terdapat dua data yang perlu diuji normalitasnya yaitu data variabel $\mathrm{X}$ (Fasilitas Belajar) dan variabel Y (Hasil Belajar). Interpretasi hasil perhitungan yang dilakukan dengan membandingkan $\chi^{2}$ hitung dengan $\chi_{\text {tabel }}^{2}$ untuk $\alpha=0,05$ dengan $\mathrm{dk}=\mathrm{k}-1$. Hasil perhitungan uji normalitas interpretasi dilakukan dengan

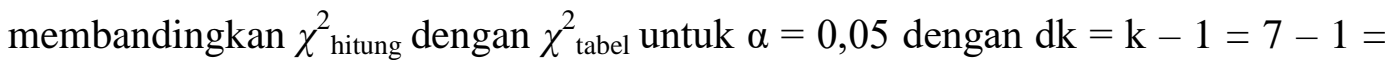
6, maka dicari pada tabel chi-kuadrat didapat $\chi_{\text {tabel }}^{2}$ sebesar 12,259. Sehingga sesuai dengan kaidah menyatakan bahwa $\chi^{2}$ hitung $=2,729<\chi^{2}$ tabel $=12,259$ berarti data variabel $\mathrm{X}$ berdistribusi normal. Sedangkan hail perhitungan uji normalitas interpretasi dilakukan dengan membandingkan $Y^{2}$ hitung dengan $Y_{\text {tabel }}^{2}$ untuk $\alpha=$ 0,05 dengan $\mathrm{dk}=\mathrm{k}-1=7-1=6$, maka dicari pada tabel chi-kuadrat didapat $Y_{\text {tabel }}^{2}$ sebesar 12,259. Sehingga sesuai dengan kaidah menyatakan bahwa $Y^{2}{ }_{\text {hitung }}=$ $1,839<Y_{\text {tabel }}^{2}=12,259$ berarti data variabel $\mathrm{Y}$ berdistribusi normal. Berdasarkan uji normalitas yang menyatakan bahwa data variabel $\mathrm{X}$ dan variabel $\mathrm{Y}$ berdistribusi normal, maka selanjutnya dilakukan uji linieritas. Hasil dari uji linieritas $\mathrm{X}$ dengan $\mathrm{Y}$ didapati bahwa $\mathrm{F}_{\text {hitung }}=0,080<\mathrm{F}_{\text {tabel }}=2,19$ hal ini berarti data berpola linier. 


\section{Uji Hipotesis}

Berdasarkan hasil perhitungan uji hipotesis. Korelasi antara $\mathrm{X}$ dengan $\mathrm{Y}$ sebesar 0,613 bertanda positif dengan kriteria tinggi. Kemudian mencari kontribusi antara variabel $\mathrm{X}$ dengan variabel $\mathrm{Y}$ sebagai berikut. $\mathrm{KD}=\mathrm{r} 2 \times 100 \%$ $=0,614^{2} \times 100 \%=37,70 \%$.

Berdasarkan perhitungan tersebut kontribusi variabel X terhadap variabel Y sebesar 37,70\% sedangkan 62,30\% dipengaruhi oleh faktor lain di luar penelitian ini. Hal ini menandakan hipotesis diterima, yang mana dapat disimpulkan terdapat hubungan yang positif dan signifikan antara sikap dalam menggunakan fasilitas belajar di sekolah dengan hasil belajar peserta didik kelas V Sekolah Dasar Negeri 01 Gapura.

\section{Pembahasan}

Berdasarkan hasil penelitian terbukti bahwa ada hubungan antara fasilitas belajar dengan hasil belajar dan fasilitas menjadi alat untuk menstimulasi terjadinya proses pembelajaran oleh peserta didik yang berlangsung di sekolah. Dengan kata lain fasilitas yang memadai dapat membuat peserta didik khususnya kelas V SD Negeri 01 Gapura pembelajarannya lebih terfokus karena adanya fasilitas yang lengkap dan sesuai dengan standar dan hasil belajar pun menjadi lebih baik.

Juga berdasarkan penelitian pendahuluan yang telah peneliti laksanakan masih banyak terdapat peserta didik dengan hasil belajar yang rendah. Setelah peneliti melakukan pengamatan langsung terhadap peserta didik tersebut peneliti menemukan masalah bahwa hasil belajar peserta didik tersebut rendah salah satunya disebabkan oleh faktor kurang mendukungnya fasilitas belajar yang dimiliki sekolah, seperti yang dikemukakan oleh Susanto (2016: 5) "hasil belajar yaitu perubahan-perubahan yang terjadi pada diri peserta didik, baik yang menyangkut aspek kognitif, afektif, dan psikomotor sebagai hasil dari kegiatan belajar". Kemudian fasilitas belajar seperti yang dikemukakan oleh Gunawan (2011: 42) ialah benda-benda yang siap pakai dalam proses pembelajaran sehingga proses pembelajaran semakin efektif dan efisien guna membantu 
tercapainya tujuan pendidikan yang telah ditetapkan. Hal ini telah dikemukakan dalam Permendiknas Nomor 24 Tahun 2007 bahwa sebuah SD/MI sekurang kurangnya memiliki prasarana sebagai berikut: (1) Ruang kelas, (2) Ruang perpustakaan, (3) Laboratorium IPA, (4) Ruang pimpinan, (5) Ruang pendidik, (6) Tempat beribadah, (7) Ruang UKS, (8) Jamban, (9) Gudang, (10) Ruang sirkulasi, dan (11) Tempat bermain/berolahraga.

Oleh karena itu, penelitian ini bertujuan untuk mengetahui hubungan antara persepsi peserta didik tentang fasilitas belajar di sekolah dengan hasil belajar peserta didik kelas V SD Negeri 01 Gapura Tahun Ajaran 2021/2022. Pengambilan data dengan menggunakan observasi dan angket. Observasi digunakan untuk menilai secara langsung fasilitas belajar yang dimiliki sekolah. Angket digunakan untuk mengetahui hubungan antara persepsi peserta didik tentang fasilitas belajar di sekolah dengan hasil belajar peserta didik kelas V di SD Negeri 01 Gapura Tahun Ajaran 2021/2022.

Berdasarkan indikator angket persepsi peserta didik tentang fasilitas belajar di sekolah dengan total 20 pernyataan, hasil analisis data yang di dapat bahwa persepsi peserta didik tentang fasilitas belajar di sekolah termasuk dalam kategori tinggi. Perhitungan hasil penelitian yang diperoleh menunjukkan bahwa terdapat hubungan antara fasilitas belajar di sekolah dengan hasil belajar peserta didik kelas V di SD Negeri 01 Gapura. Hal tersebut menunjukan bahwa semakin lengkap dan memadainya fasilitas belajar yang di miliki sekolah maka akan semakin baik pula hasil belajar yang didapatkan oleh peserta didik.

Hal ini sejalan dengan penelitian yang dilakukan oleh Nur (2017) tentang hubungan antara Fasilitas Belajar dengan Hasil Belajar dalam mata pelajaran PKn peserta didik kelas IV di SDN 80 Popo Kabupaten Takalar. Penelitian yang dilakukan oleh Nur (2017) relevan dengan hipotesis yang peneliti ajukan yaitu terdapat hubungan yang signifikan antara fasilitas belajar dengan hasil belajar kelas V SD Negeri 01 Gapura, serta sesuai dengan teori yang dikemukakan Susanto (2016: 5) "hasil belajar yaitu perubahan-perubahan yang terjadi pada diri peserta didik, baik yang menyangkut aspek kognitif, afektif, dan psikomotor sebagai hasil dari kegiatan belajar". 
Berdasarkan hasil observasi peneliti tentang fasilitas belajar di sekolah didapatkan juga bahwa fasilitas belajar tiap sekolah memiliki perbedaan. Selanjutnya, berdasarkan uji signifikansi atau uji-f yang telah dilakukan, maka $\mathrm{f}_{\text {hitung }}=22,99>\mathrm{f}_{\text {tabel }}=4,10$. Hal ini membuktikan bahwa Ho ditolak dan Ha diterima dengan koefisien korelasi antara variabel $\mathrm{X}$ terhadap $\mathrm{Y}$ sebesar 0,611 bertanda positif dengan kriteria tinggi. Peneliti menyatakan bahwa fasilitas belajar memberikan pengaruh sebesar $37,70 \%$ terhadap hasil belajar peserta didik kelas V SD Negeri 01 Gapura. Sedangkan 62,30\% dipengaruhi oleh faktor-faktor lainnya seperti motivasi, intelegensi, sikap, gaya belajar, lingkungan belajar, perhatian dan ketekunan yang tidak dibahas peneliti dalam penelitian ini.

Berdasarkan uji hipotesis pula membuktikan bahwa semakin lengkap dan memadainya fasilitas belajar yang dimiliki oleh sekolah, maka akan semakin tinggi pula hasil belajar yang akan didapatkan oleh peserta didik. Demikian sebaliknya, semakin tidak lengkap dan tidak memadainya fasilitas belajar yang dimiliki sekolah, maka akan semakin rendah pula hasil belajar yang didapatkan oleh peserta didik.

\section{SIMPULAN}

Berdasarkan hasil analisis data penelitian dan pembahasan yang telah diperoleh, maka dapat disimpulkan bahwa ada hubungan yang positif dan signifikan antara fasilitas belajar dengan hasil belajar peserta didik kelas V SD Negeri 01 Gapura dengan memiliki taraf koefisien korelasi "tinggi". Hal ini menunjukkan bahwa fasilitas belajar (X) memiliki hubungan dengan hasil belajar (Y) sehingga hipotesis yang diajukan peneliti dapat diterima yaitu "Terdapat hubungan antara fasilitas belajar di sekolah dengan hasil belajar peserta didik kelas V di SD Negeri 01 Gapura". Artinya, lengkap dan memadainya fasilitas belajar yang dimiliki sekolah maka akan semakin baik pula hasil belajar yang didapatkan oleh peserta didik. 


\section{DAFTAR PUSTAKA}

Alex, Sobur. 2003. Psikologi Umum. Pustaka Setia, Bandung.

Arikunto, Suharsimi. 2003. Prosedur Penelitian, Suatu Praktek. Bina Aksara, Jakarta 2013. Prosedur Penelitian Suatu Pendekatan Praktik (Edisi Revisi VD). PT Renika Cipta, Jakarta

Bahri Djamarah, Syaiful. 2011. Psikologi Belajar. Rineka Cipta, Jakarta.

Barnawi, Arifin. 2012. Manajemen Sarana dan Prasarana Sekolah. Ar-Ruzz Media, Yogyakarta.

Dalyono. 2009. Psikologi Pendidikan. Rineka Cipta, Jakarta.

Daryanto, M. 2006. Administrasi Pendidikan. Rineka Cipta, Jakarta.

Djamarah, Syaiful Bahri. 2011. Psikologi Belajar. Rineka Cipta, Jakarta.

Depdiknas. 2003. Undang-Undang Republik Indonesia Nomor 20 tahun 2003 tentang Sistem Pendidikan Nasional. BSNP, Jakarta.

Fadhil, M. 2016. Pengembangan Media Pembelajaran Berbasis Video Kelas IV Sekolah Dasar. Jurnal Dimensi Pendidikan dan Pembelajaran, 3: 24-33.

Gunawan, Ary. 2011. Administrasi Sekolah: Administrasi Pendidikan Mikro. Rineka Cipta, Jakarta.

Hajar, Ibnu. 2013. Panduan Lengkap Kurikulum Tematik. Diva Press, Jogjakarta.

Hanafiah, Nanang., \& Cucu, Suhana. 2010. Konsep Strategi Pembelajaran. Reflika Aditama, Bandung.

Hamalik, Oemar. 2011. Pendekatan Baru Stratei Belajar Mengajar Berdasarkan CBSA. Sinar Baru Algesindo, Bandung.

Hermawan, Ruswandi. 2010. Metode Penelitian Pendidikan Sekolah Dasar. Jurnal Pendidikan Guru Sekolah Dasar. 4: 232-238

Jihad, Asep., \& Abdul, Haris. 2012. Evaluasi Pembelajaran. Multi Presindo, Yogyakarta.

Kasmadi \& Nia, Siti Sunariah. 2014. Panduan Modern Penelitian Kuantitatif. Alfabeta, Bandung. 
Khan, P., \& Igbal, M. 2012. Interdisciplinary. Journal of Contemporary Research in Business. 4: 211-220.

Komalasari, Kokom. 2015. Pembelajaran Kontekstual Konsep dan Aplikasi. Refika Aditama, Bandung.

Majid, Abdul. 2014. Pembelajaran Tematik Terpadu. PT Remaja Rosdakarya, Bandung.

Mulyasa, E. 2008. Standar Kompetensi dan Sertifikasi Guru. PT Remaja Rosdakarya, Bandung.

Muncarno. 2016. Statistik Pendidikan. PT Arthawarna, Lampung.

Nuha, A. 2018. Pengaruh Fasilitas Belajar terhadap Hasil Belajar Pelajaran Kesenian Siswa Kelas IV SDN Bandula 2 Malang. (Skripsi). Universitas Malang, Malang

Nur, J. 2017. Hubungan antara Fasilitas Belajar dengan Hasil Belajar dalam Mata Pelajaran PPKn. (Skripsi). Universitas Muhammadiyah Makassar, Makassar.

Panuntun, B. (2015). Pengaruh Bimbingan Orang Tua dan Fasilitas Belajar terhadap Prestasi Belajar Siswa Kelas V SDN 1 Tremes Sidoharjo Tahun Ajaran 2014/2015. (Skripsi). Universitas Muhammadiyah Surakarta, Surakarta.

Permendiknas. 2017. Standar Sarana dan Prasarana Untuk Sekolah Nomor 24. BSPN, Jakarta.

Riduwan, Sunarto. 2014 Pengantar Statistika untuk Pendidikan Sosial, Ekonomi, Komunikasi, dan Bisnis. Alfabeta, Bandung

Rusman. 2012. Pembelajaran Tematik Terpadu Teori, Praktik dan Penilaian. PT Rajagrafindo Persada, Jakarta.

. 2015. Pembelajaran Tematik Terpadu Teori, Praktik dan Penilaian. PT Rajagrafindo Persada, Jakarta.

Sardiman. 2012. Interaksi dan Motivasi Belajar Mengajar. PT Raja Grafindo Persada, Jakarta.

Slameto. 2013. Belajar dan Faktor-faktor yang Mempengaruhi. Rineka Cipta, Jakarta.

2015. Belajar Dan Faktor-Faktor yang Mempengaruhi. Rineka Cipta, Jakarta. 
Sopianti, Popi. 2010. Manajemen Belajar Berbasis Kepuasan Siswa. Ghalia Indonesia, Bogor.

Sri, Haryati. 2017. Belajar \& Pembelajaran Berbasis Cooperative Learning. Graha Cendikia, Jakarta.

Sudjana, Nana. 2009. Penilaian Hasil Proses Belajar Mengajar. Remaja Rosdakarya, Bandung. 2016. Penilaian Hasil Proses Belajar mengajar. Rosdakarya, Bandung.

Sugiyono. 2010. Metode Penelitian Pendidikan. Alfabeta, Bandung. . 2014. Metode Penelitian Pendidikan. Alfabeta, Bandung. 2013. Metode Penelitian Kuantitatif, Kualitatif, dan Kombinasi (Mixed Methods). Alfabeta, Bandung.

. 2016. Metode Penelitian Pendidikan. (Pendekatan kuantitatif, kualitatif dan $R \& D$ ). Alfabeta, Bandung.

Sukardi. 2012. Evaluasi Pendidikan Prinsip dan Operasionalnya. Bumi Aksara, Jakarta.

Sulistiasih. 2018. Evaluasi dan Asesmen Pembelajran SD. Graha Ilmu, Yogyakarta.

Suryosubroto. 2009. Proses Belajar Mengajar di Sekolah. Rineka Cipta, Jakarta.

Susanto, Ahmad. 2016. Teori Belajar dan Pembelajaran di Sekolah Dasar. PT Fajar Interpratama Mandiri, Jakarta.

Uno, Hamzah, B. 2008. Orientasi Baru Dalam Psikologi Pembelajaran. PT Bumi Aksara, Jakarta.

Widaryanto, Sidik. 2016. Hubungan antara Fasilitas Belajar dengan Hasil Belajar Siswa Kelas IV di SDN Gugus Wijaya Kusuma Kecamatan Ngaliyan Kota Semarang. (Skripsi). Universitas Negeri Semarang, Semarang.

Yusra, A., Sugiharto, D. Y. P., \& Sutoyo, A. 2017. Model Bimbingan Belajar Berbasis Prinsip-prinsip Belajar dalan Islan untuk Meningkatkan Kemanfaatan Ilmu. Jurnal Bimbingan Konseling, 6: 106-112.

Yusuf, Muri. 2014. Metode Penelitian: Kuantitatif, Kualitatif \& Penelitian Gabungan. Prenada Media Group, Jakarta. 